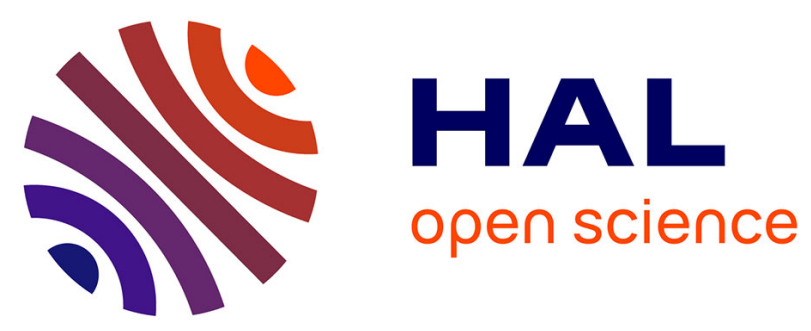

\title{
Highland and lowland waters: The Western Sierra Madre, the water tower of Northern Mexico
}

Luc Descroix, José Luis Gonzalez Barrios, David Viramontes, Eva Anaya, Brouste Laurent, Arnaud Bollery

\section{- To cite this version:}

Luc Descroix, José Luis Gonzalez Barrios, David Viramontes, Eva Anaya, Brouste Laurent, et al.. Highland and lowland waters: The Western Sierra Madre, the water tower of Northern Mexico. Revue de Géographie Alpine / Journal of Alpine Research, 2004, 92 (3), pp.17-26. 10.3406/rga.2004.2305 . ird-02153570

\section{HAL Id: ird-02153570 \\ https://hal.ird.fr/ird-02153570}

Submitted on 12 Jun 2019

HAL is a multi-disciplinary open access archive for the deposit and dissemination of scientific research documents, whether they are published or not. The documents may come from teaching and research institutions in France or abroad, or from public or private research centers.
L'archive ouverte pluridisciplinaire HAL, est destinée au dépôt et à la diffusion de documents scientifiques de niveau recherche, publiés ou non, émanant des établissements d'enseignement et de recherche français ou étrangers, des laboratoires publics ou privés. 


\title{
Highland and lowland waters : The Western Sierra Madre, the water tower of Northern Mexico

\author{
Monsieur Luc Descroix, M. José Luis Gonzalez Barrios, Monsieur David Viramontes, \\ Eva Anaya, M. Laurent Brouste, Monsieur Arnaud Bollery
}

\begin{abstract}
Abstract: The Western Sierra Madré constitutes a natural water tower for the whole of northern Mexico. Rainfall amounts and runoff coefficients have enabled it to provide water to its neighbouring arid and semi-arid areas. However, considerable degradation of the mountain landscape has been observed for some decades. Overgrazing and deforestation have lead to soil degradation that has resulted in hydrological changes, and particularly a reduction in soil water retention in the catchment areas. In addition, piedmont oases have been transformed into irrigated areas. The Laguna irrigated area is located at the outlet of the Nazas river in the plain, to the south of the Chihuahuan desert. This area suffers not only from a reduction in water supply, relating to the severe drought conditions (since 1992), but also from substantial over-consumption of water. The need to ensure the natural equilibrium, in both mountain and piedmont areas, and to achieve a sustainable farming system should help reinforce the current changes taking place in water management.
\end{abstract}

\section{Citer ce document / Cite this document :}

Descroix Luc, Gonzalez Barrios José Luis, Viramontes David, Anaya Eva, Brouste Laurent, Bollery Arnaud. Highland and lowland waters : The Western Sierra Madre, the water tower of Northern Mexico. In: Revue de géographie alpine, tome 92, n³, 2004. Mélanges 2004. pp. 17-26;

doi : 10.3406/rga.2004.2305

http://www.persee.fr/doc/rga_0035-1121_2004_num_92_3_2305

Document généré le 06/06/2016 


\section{Higland and lowland waters : The Western Sierra Madre, the water tower of Northern Mexico}

\section{Luc Descroix', José Luis Gonzalez Barrios², David Viramontes ${ }^{3}$, Eva Anaya ${ }^{4}$, Laurent Brouste', Arnaud Bollery'}

IRD, Laboratoirc d'étude des Transferts en Hydrologie et Environnement (ITHE)

UR012, BP 5.3, 38041 (irenoble cedex 2.

descroix (iird.ne

Cenid Raspa-INIFAP, AP 225-3, parcque industrial, 35071 (jomez lalacio, 1)(;), Mexiçue.

gonzalez.barrios $a_{i \text { itesm.mx }}$

'Instituto Mexicano de Tecnología del Agua (MTA), Paseo (uahnáhuac 8532, (P' 62550 Jiutepec, Morclos, México. davidv@rlaloc.imta.mx

'Unidad Regional del Semidesierto. SEMARNAT, Bd M. Aleman, 900, col. Constimyentes, (dd Lerdo, I)(io, Mexique. n eva rez(i)hotmail.com

Unité Kau, Conseil Régional de l’Isère, 38000 Grenoble.

a.bollery@cg.38.fr

\begin{abstract}
The Western Sierra Madre constitutes a natural water tower for the whole of northern Mexico.

Rainfall amounts and runoff coefficients have enabled it to provide water to its neighbouring arid and semi-arid areas.

However, considerable degradation of the mountain landscape has been observed for some decades. Overgrazing and deforestation have lead to soil degradation that has resulted in hydrological changes, and particularly a reduction in soil water retention in the catchment areas.

In addition, piedmont oases have been transformed into irrigated areas. The Laguna
\end{abstract}

irrigated area is located at the outlet of the Nazas river in the plain, to the south of the Chihuahuan desert. This area suffers not only from a reduction in water supply, relating to the severe drought conditions (since 1992), but also from substantial over-consumption of water.

The need to ensure the natural equilibrium, in both mountain and piedmont areas, and to achieve a sustainable farming system should help reinforce the current changes taking place in water management.

Keywords: overexploitation of resources, water table, oasis, natural water tower

This paper should have been published in issue $n^{\circ} 1 / 2004$ of the RGA, dedicated to Alain Morel, one of the best known French geographers working on semi-arid and arid mountain areas. This was not possible in the end, but we would nevertheless like to extend our thanks to Alain Morel for the invaluable help he provided the North Mexican program as the PhD thesis director of David Viramontes. 
$\mathrm{T}$ he aim of the programme "Water use and management in a catchment area of Northern Mexico "was to determine, over an eight year period (1992-2000), the impact of catchment area overexploitation on water resources and their management. For this purpose, three experimental areas were selected to represent, as far as possible, the various climates of the entire Nazas Aguanaval basin, covering a total area of $92000 \mathrm{~km}^{2}$. The first area, with a sub-humid climate (mean annual rainfall ranging from 500 to 900 $\mathrm{mm}$ ), is located in the Western Sierra Madre, in the upper Nazas basin, and constitutes the subject of this paper. 'The second area, the Atotonilco ranch, in a semi-arid area (300$500 \mathrm{~mm}$ ), is situated on the Nazas-Aguanaval interfluve, while the third area, which has also been the subject of another earlier scientific study (Grunberger and Janeau, 2004), is in the Mapimi desert, where rainfall is less than $300 \mathrm{~mm}$.

\section{Introduction}

Northern Mexico is a relatively new country compared with the South, with its history of ancient civilisations. Only a few of the Indian populations which occupied the North of Mexico, as in the South West of the United States, had a long period of settlement (for instance, the civilisations of Mesa Verde in New Mexico and Paquimé in the North of Chihuahua state). Most of the others were nomad tribes who moved according to the seasons: Apaches, Comanches and, in the mountains, relatively small ethnic groups who became sedentary partly to be escape the attacks of the Spanish settlers. Some of these groups were protected from the colonial armies by the Spanish Jesuits. Such was the case of the Tarahumaras who were almost wiped out at the beginning of the $17^{\text {th }}$ century.

Thus, the exploitation of land, first for minerals, then for grasslands, and more recently for forestry resources, has always been carried out with a "mining "type of attitude, meaning that a resource can be exploited as long as it is economically viable, without taking into account the future and whether or not the resource is renewable. The great civilisations of the Yucatan peninsula and, to an even greater extent those of the Tehuacan Valley (Puebla and Oaxaca States, in southern Mexico), had practised agriculture for several thousand years (three millennia at least), while the settlers of the pastures and forests of the western Sierra Madre had depleted them after only three of four decades of use.

The objective of the programme "Water use and management in a catchment area of Northern Mexico ", which was set up following a agreement between the IRD and the Cenid Raspa (INIFAP, Gomez Palacio, Durango State, Mexico), was to identify changes in the hydrological regime induced by land-use changes. Deforestation, and overgrazing in particular, has led to drastic changes in soil surface features, and consequently in hydrodynamic soil conditions. This has caused modifications to river regimes.

In the medium term, this situation threatens resources available downstream where all the basin's water (and even more, given that fossilised water is also being extracted from an overexploited watertable) is used in the extensive Laguna irrigation district (160000 ha equipped). If the sustainability of the resource is not ensured upstream through land use changes, it is the very economy of the dynamic downstream area that will be 
threatened. There is therefore an urgent need to develop solidarity between upstream and downstream areas and to set up a sound vegetation-soil-water management system to prevent the decline of an entire region.

\section{A water tower under threat}

The Western Sierra Madre is without doubt the main source of borh surface and ground water in the North of Mexico. It also supplies, via the rio Conchos, the lower valley of the Rio Bravo del Norte (referred to as the Rio Grande by Americans), where it maintains the low-water flow of this river forming the border between the two countries (figure 1 ).

Table 1 provides a list of the main dams located along the piedmont of this range, on both the Pacific side (where most are situated) and inland eastern side. It may be observed that six of them have a capacity of more than $3 \mathrm{~km}^{3}$ (compared with the biggest of the French dams, Serre Ponçon in the Hautes Alpes department, which has a maximum capacity of $1 \mathrm{~km}^{3}$ ).

In addition, isotopic dating techniques (Brouste, 1997) have also shown the Western Sierra Madre to be the main source of the north Mexican altiplano water table. Brouste showed that the residence time of Laguna groundwater was shortest along the river axis, where flows are renewed by supplies coming from the West (Sierra Madre), and that it increased with distance from the river, both northward and southward.

All the research conducted in the Sierra Madre from 1992 to 2001 was focused on determining land, soil and vegetation degradation, and on defining and modelling the impact of such changes on the water resources and their sustainability. The conclusions of these studies are summarised in the thesis of David Viramontes (2000).

\section{GRASSLAND AND I:ORESI' OVEREXPIOITATIOION}

The above research identified spatial and landscape changes that have taken place over several decades in almost the entire Western Sierra Madre.

According to opinion surveys conducted among the local population, and confirmed by field data (Descroix et al., submitted), overgrazing has become generalized over the past four or five decades in all the mountain savannah areas, and increasingly in the forest areas. On average, there are from two to four times as many cows as the number required to maintain a sustainable grassland resource.

At the beginning of the 1970s, the upper Nazas basin, which is representative of the entire Sierra Madre, was open to forest harvesting. Then the states of Durango and Chihuahua rapidly became the first two timber providers in Mexico. However, inadequate management (and possibly the illegal exploitation and sale of timber resources) led to serious deforestation, with more than half the forested area in the upper Nazas basin disappearing in 30 years (Viramontes, 2000). 


\begin{tabular}{|c|c|c|c|c|c|c|}
\hline Name of dam & River & State & $\begin{array}{l}\text { Year of } \\
\text { completion }\end{array}$ & $\begin{array}{l}\text { Catchment } \\
\text { area } \mathbf{k m}^{2}\end{array}$ & $\begin{array}{l}\text { Total capacity } \\
{ }^{*} 10^{6} \mathrm{~m}^{3}\end{array}$ & $\begin{array}{l}\text { Irrigated area } \\
\text { irriguée en ha }\end{array}$ \\
\hline 1- A.L. Rodriguez & Sonora & Sonora & 1948 & 21900 & 253 & 10000 \\
\hline 2-Alvaro Obregon & Yaqui & Sonora & 1953 & 73500 & 3000 & 220000 \\
\hline 3- Miguel Hidalgo & Fuerte & Sinaloa & 1956 & 29600 & 3290 & 230000 \\
\hline 4- A Lopez Mateos & Humaya & Sinaloa & 1964 & 11000 & 3160 & 126100 \\
\hline 5- Sanalona & Tamazula & Sinaloa & 1949 & 3250 & 1095 & 95000 \\
\hline 6- J. Lopez Portillo & San Lorenzo & Sinaloa & 1981 & 8200 & 3400 & 260000 \\
\hline 7- La Boquilla & Conchos & Chihuahua & 1916 & 28000 & 3990 & 39700 \\
\hline 8- Lazaro Cardenas & Nazas & Durango & 1946 & 19000 & 4400 & 160000 \\
\hline
\end{tabular}

Table 1. The main dams filled by rivers flowing from the Western Sierra Madre

\section{CONSEQUENCES FOR THE LANDSCAPE}

As a result of deforestation, soils experienced significant degradation, linked to both the disappearance of their organic matter and the removal of fine particles by runoff and hydric erosion. The latter is typically a laminar (or areal) type of erosion, with few gullies, these being located in a few localised areas (the bottoms of valleys and depressions generally) where soils are deep (Descroix et al., submitted).

The main impact on the landscape was the degradation of green pastureland (Boutrais, 1994 ; Viramontes, 2000) due to an invasion by ligneous vegetation and a marked increase in pebbles and blocks in topsoil cover. It seems that the increase in stones is related to the erosion and transportation of all the fine particles, removed by splash and runoff.

\section{CONSEQUENCES FOR WATER RESOURCES}

It has been demonstrated that, at the scale of the plot and small catchment areas (some $\mathrm{km}^{2}$ ), there has been a marked increase in erosion and runoff, particularly immediate runoff, and a rapid decrease in surface flows after rainfall events. A ten-fold rise in the runoff coefficient (from 0.02 to 0.2 ) and a one hundred-fold rise in erosion (from $1 \mathrm{~g} / \mathrm{m}^{2}$ to $133 \mathrm{~g} / \mathrm{m}^{2}$ ) have been observed following deforestation and an increase in cattle trampling. These same factors have also led to a significant increase in soil bulk density (from 1.23 to 1.55 ) and a marked reduction in soil hydraulic conductivity (from 77 to $24 \mathrm{~mm} / \mathrm{h}$ on average).

At the scale of the major catchment areas, rainfall and runoff data provided by the Mexican monitoring network on the two basins of the Sextin $\left(5051 \mathrm{~km}^{2}\right)$ and Ramos $\left(7130 \mathrm{~km}^{2}\right)$ rivers, constituting the two upper branches of the Rio Nazas, have enabled the following changes to be identified over the last three decades:

- a decrease in catchment response time;

- an increase (decrease) in the quick flow (base flow) component of total flows;

- a reduction in the soil water capacity of watersheds, demonstrated by means of the Nazasm model (Descroix et al., 2002); 
- a decrease in the mean duration of floods. In addition, changes in both the "baseflow recession index " and the " two-day recession index " (as defined by Tallaksen, 1995) demonstrated that runoff was increasingly irregular, with baseflow constantly decreasing during this period.

The upper Nazas basin is characterized by a mean runoff coefficient of $15 \%$, with an average annual total flow of $1 \mathrm{~km}^{3}$. The basin represents $20.5 \%$ of the total area of the Nazas Aguanaval basin, but it yields $90 \%$ of the total surface flow (and probably a similar proportion of the ground water) of the whole basin.

However, overexploitation of land resources in this upper basin is threatening its role as the area's natural water tank, owing to the drastic changes that have already been observed in runoff conditions and the fact that there is no evidence that this situation is likely to change in the future. The entire upper basin is becoming deserted, with some rural areas having lost up to $90 \%$ of their population in the last 10 years. A major factor in emigration has been the attraction for the working population of the better conditions and salaries in the United States. The economy of the south western states and the Chicago area (the two main destinations for migrants from Durango State) has been particularly dynamic in recent years (Inard Lombard, 2000).

In spite of significant rural depopulation, however, the overexploitation of land resources remains a problem and in certain areas is even more marked than before. Stock breeding is still the main activity, but herds have been increased with new selected cows, bought with the funds sent by migrants. These new varieties are more productive but do not graze over such wide areas as the local breeds, thus contributing to overgrazing near the villages and water holes. The fact that many herdsmen have also migrated along with other workers to the United States has exacerbated the problem. In addition, the smaller remaining populations find it increasingly difficult to control the illegal deforestation of their lands by external operators.

All these elements explain why the hydrological characteristics of the hillslopes of the Western Sierra Madre have changed over recent decades. Flow characteristics are becoming increasingly irregular, while the soil water content in catchment areas is decreasing. The area's natural water tower is threatened, probably duc to the overexploitation of soil and vegetation resources. Indeed, land use change is the only noticeable modification in the upper Nazas basin at the present time.

\section{An anaemic piedmont oasis}

\section{A COMPARTMENTALIZED ENVIRONMENI}

The eastern piedmont of the Sierra Madre comprises a variety of mid-altitude mountain landscapes. The high plateaux (ranging from 2500 to $1500 \mathrm{~m}$ ) slope gently eastward and are formed by Secondary sedimentary terrains that were raised in the west by the uplift of the Western Sierra Madre. These sedimentary terrains become increasingly folded in the east, where they reach the border of the Chihuahuan desert and its endoreic depressions. Some of these ranges almost join with the Eastern Sierra Madre, a great 
folded range (composed of Jurassic and Cretaceous limestones) with a North-South axis. Transversal ranges make the North Mexican Altiplano (in fact, the entire southern part of the Chihuahuan desert) appear little like a plateau. It is actually a series of mostly endoreic depressions, the bottoms of which range from 1300 to $800 \mathrm{~m}$, separated by limestone relief which can locally reach $3000 \mathrm{~m}$ (Sierra de Jimulco at the border of the States of Durango and Coahuila). This kind of topography, as well as the exoreic hydrographic network from more humid periods in the past (glacial periods and certain inter-glacials) have been described by an IRD research team (Grunberger and Janeau, 2004). The closure of relief and the aridification of the post-Wisconsinian climate led to the formation of a series of endoreic depressions (twenty in total) which concern most of the extension of the Chihuahuan desert.

It is probably during the Holocene that the dry climate considerably reduced surface flows, thus preventing them from passing from one depression to another. This situation was aggravated by the fact that large volumes of colluvia accumulated there during the last glacial period (Wisconsin), raising the level of the sills (Descroix, 1996) and creating a very recent period of endoreism.

Upstream of the Laguna, the Nazas and Aguanaval rivers, still with perennial flows, cross calcareous folded strata, through canyons which, on the approaches to the desert, constitute real piedmont oases. The Canyon de Fernandez, immediately upstream of the Gomez Palacio/Torreon urban area (Figure 3) is a good example.

However, the natural environment and the flows have been substantially modified on each river since the construction of the dams and hydraulic equipment. Immediately upstream of the Canyon de Fernandez, the Las Tortolas lake (400 million $\mathrm{m}^{3}$, retained by the Francisco Zarco dam) acts as a regulatory reservoir from which the water is provided to the irrigation area. Discharges are adapted to agricultural needs: April and May for sowing, and then, from June to September, a constant discharge for the irrigation of the Laguna.

Among the mountain ranges that separate the different endoreic basins of the Chihuahuan desert, those surrounding the Laguna are the highest. The most southerly range, the Sierra de Jimulco (3150 $\mathrm{m}$ at the Cerro Las Nopaleras), is high and isolated enough to have numerous endemic plant species. These mountain ranges constitute the last refuge for wild fauna.

The anthropisation of surface flows resulted in a considerable increase in evaporation in the depressions and particularly in the largest of these, La Laguna. 'The Nazas and Aguanaval rivers transport an average annual flow of 1100 million $\mathrm{m}^{3}$. Instead of filling the Mayran and Viesca lagoons, which in past periods were able to conserve water for several successive years, the water is now stored behind the Lazaro Cardenas dam (El Palmito Lake, with a maximum capacity of $4 \mathrm{~km}^{3}$ ), commissioned in 1946 and located $200 \mathrm{~km}$ upstream of the Zarco dam. Since 1946, basin flows have exceeded the capacity of the (ardenas reservoir on only two occasions, in September 1968, and again in September 1991 and the following winter (January, 1992), due to an El Niño event and the resulting cold season (Viramontes, 2000). 


\section{A RECURRENT DROUGHT WITH EFFECTS AGG GRAVATED BY OVEREXPIOITATION}

At the moment, the flow of the Rio Nazas has not been sufficiently modified to have an impact on water supplies to the Laguna irrigation district, developed around the natural oasis of Lerdo-Gomez Palacio. The oasis can be seen in Figure 2, showing the Comarca Lagunera historic region in 1787 . However, maintenance of a water consumption level that is twice as high as the yearly renewable storage volume has resulted in a deficit that is being compensated for by over-pumping from the water table. Such a deficit cannot be maintained for long since it threatens the sustainability of not only the water table but also the local economy. This point has not been reached yet, but the imbalance is leading to severe problems when long droughts occur, as is the case at the moment. The present drought, which began in 1992, has substantially reduced surface runoff to amounts of between 4 and $50 \%$ of the mean value (except in 1996, the only wet year; 2003 was also a good year for water supplies). The deficit has been partially met by increased pumping from the water table. The drought has caused the collapse of economic activity in the Laguna district. In the last few years, the irrigated area has been reduced from an initial 160000 hectares to between 5000 and 40000 hectares, in order to match water demand with available supplies.

Figure 2 also indicates that an oasis, the Laguna de Parras, existed where the Rio Aguanaval joined the plain. Named after the only town in the region at that time, the Laguna de Parras later became known as the Laguna de Mayran. The main change brought about by the installation of hydraulic equipment in recent years is the quasi disappearance of this oasis. Nevertheless, today it still boasts the oldest wine cellar on the entire American continent, having been in operation since 1598. As shown earlier, this laguna became partially and sometimes completely filled with each rainy season.

The modification of surface flows, however, has been accompanied by a severe overexploitation of water resources. Thus, since the beginning of the 1950s, only a few years after the completion of the Palmito dam, annual water consumption has been estimated at more than $2.10^{\prime \prime} \mathrm{m}^{3}$ (and even close to $3.10^{\circ} \mathrm{m}^{3}$ in certain years), whereas the mean annual volume provided by rivers is $1.1 .10^{\prime \prime} \mathrm{m}^{\prime}$ and the annual mean water table recharge $300.10^{\prime} \mathrm{m}^{3}$. (It has been shown that this recharge comes mainly from the upper basin). Figure 4 shows how the water level has fallen since 1950 .

The piezometric level has fallen $1.75 \mathrm{~m}$ per year on average for the past fifty years. In some areas, the water is at depths of almost $200 \mathrm{~m}$, whereas it was very close to the surface seventy years ago.

This has led to some regrettable consequences:

- Increase in pumping costs: this fact has gone largely unnoticed because of the huge increases in the price of water $(1000$ or 10000 times greater) when the new Mexican water management system was inaugurated in the $1990 \mathrm{~s}$. In comparison, the progressive rise in the cost of water extraction because of the greater depths involved has been comparatively painless. However, numerous ejidos (rural communities) have failed during recent years in the Laguna, while others survive only by selling their water rights and abandoning any agriculrural activity. 
- Increase in salt content of water (deeper water here is more saline) and especially the release of arsenic when the piezometric level reaches certain geological strata containing this element. A great number of wells in the Laguna provide water that should no longer be used for irrigation purposes, and even less for drinking water. However, due to the lack of other sources in this arid endoreic basin (annual rainfall amount is less than $200 \mathrm{~mm}$ in the centre of the depression), it is often used for drinking water, leading to serious health problems.

\section{DRASTIC MANAGEMENT CHANGES IN WATER RESOURCES}

Recently, water managers in the Comarca Lagunera district have adopted a voluntarist but socially risky point of view. They appear resolved to the fact that agricultural activities that are heavy water consumers (such as the growing of alfalfa crops that represent $80 \%$ of the total area and are used for intensive stock breeding) must gradually disappear if large volumes of water are to be reallocated to new activities capable of creating more added value. 'Two new golf courses have been opened, and the gradual release of former cropland is making way for the arrival of a new amusement park, new cattle ranches (that will use imported fodder) and new industries. This appears an opportunity to create more production and use less water.

Nevertheless, the future of water resources is closely linked to soil and vegetation conservation, particularly in the upper basins. In 2001, the Mexican President inaugurated the "Crusade for Water and Forests " with the aim of making both inhabitants and water resource managers more aware of the importance of conserving these resources, in line with the objectives of sustainable development.

\section{Conclusion}

Solidarity between upstream and downstream water users is essential for sound river basin management, particularly in a semi-arid area. The mountains (the western Sierra Madre in this case) act as a natural water tower, and downstream areas are completely dependent on it. The Bolson de Mapimi, in the southern part of the Chihuahuan desert, depends entircly on the Nazas basin for both surface and ground water. Water flow changes in the mountain areas, linked to overexploitation of the land resources, could eventually threaten the water resources from upstream. They have been particularly affected by the long drought since 1992.

The current water management system, however, appears little concerned about planning for future water use. There is no possibility of achieving sustainability when annual water consumption is double the renewable volume provided by the mountain areas.

This kind of scarcity situation requires difficult decisions to be made with regard to resource management and water sharing, and causes tensions at a geopolitical level. Although the transfer of water from upstream to downstream areas enables water to be used in the areas where the population is settled, it could also be considered as plunder by the inhabitants of the Sierra Madre. The latter could legitimately claim that it is more 
expedient to use water where it is relatively abundant, that is in the mountain areas.

Today, the Nazas Basin is therefore threatened simultaneously: upstream, by a reduction in available surface water due to soil degradation and subsequent changes in runoff; downstream, by a drop in the water table and declining water quality.

It is probably time to adopt a new approach to water management that is more focussed on achieving resource sustainability. Such an approach must include sound planning measures in the upper basin aimed at preserving the soil-vegetation-water resource, which is currently being overexploited. This will require a new level of solidarity between upper and lower basin users, which could be based on two different scenarios:

- the current situation is maintained (the most likely hypothesis), with agriculture and a high level of water consumption in the lower basin (Laguna irrigation district). If upper basin users agree not to exploit the water, they should be compensated. Conservation measures must also be introduced for pastures and forests to ensure the future of the soilvegetation-water resource;

- only a limited amount of water is attributed to downstream areas, to allow urban development and a few industrial activities, and priority is given to agricultural activities in the upper basin. However, this results in a decrease in the value of production supported by a given volume of water (lower than that of the current agro-industrial activities of the Laguna).

\section{Acknowledgements}

We would like to thank a number of institutions that supported this study, and in particular the ISIS program (from the CNES, the French Spatial Research Centre) which helped us by providing low-cost satellite images to analyse the evolution of the vegetation cover. Our thanks are also extended to the IMTA (Instituto Mexicano de Tecnología del Agua) of Cuernavaca, which supplied the hydrological and climatological data, and the ECOS NORD (France) and ANUIES (México) program which assisted us by facilitating the field measurement studies. 


\section{References}

BoUtrais J., 1994. - Eleveurs, bétail et environnement. A la croisée des parcours. ORSTOM -Centre d'études africaines, pp. $303-319$.

Broust: L., 1997. - Hydrochimie et géochimie isotopique de la nappe phréatique de la Comarca Lagunera (Nord Mexique). Thèse de l'Université Paris 11 Orsay, 225 p.

Descroix L., 2004. - " Hydrographie des lagunes de Mayran et Viesca : endoréisme et anthropisme ". Les playas du désert de Chibuahua. Influence des concentrations salines sur un milieu semi-aride. On press at Editions de l'IRD.

Descroix L., Estraida J., Nouveiot J.F., Thiébaux J.P., 1997. - L'hydrologie du bassin de La Ventana (Coah). Rapport technique, 20 p.

Descroix L., Viramontes D., Vauci.in M., Gonzalez Barrios J.L., Esteves M., 2001. - "Influence of surface features and vegetation on runoff and soil erosion in the western Sierra Madre (Durango, North West of Mexico) ». Catena, 43-2, p 115-135.

Descroix L., Nouvelot J.F., Vauci.in M., 2002. - "The role of the antecedent precipitation index on runoff functions : application to the western Sierra Madre (North-west Mexico). " Journal of Hydrology, 263, p 114-130.

Descroix L., Gonzalez Barrios J.L., Viramontes D., Poulfonard J., Esteves M., BOI.L.R.RY A. - Gully and sheet water erosion on subtropical mountainous slopes : impact of land use changes and consequences on scale effect. (Article submitted to Catena).

ESTRADA J., 1999. - Importance et fonctionnement des petits barrages dans une zone semiaride du Nord-Mexique. Thèse de l'Université Montpellier 2, 450 p.

Grunberger O., Janeau J.L., 2004. - Les playas du désert de Chihuahua. Influence des concentrations salines sur un milieu semi-aride. On press at the Editions de l'IRD, Paris, $350 \mathrm{p}$.

Hernandez A.P., 2001. - La Antigua Laguna. Bermejillo (Dgo, Mexique). Ediciones de la Universidad Autonoma de Chapingo Uruza, 207 p.

INARD LOMBARD B., 2000. - Les causes et conséquences de l'émigration de la population de quatre communautés rurales de la Sierra Madre Occidentale (Nord Mexique). Mémoire de maîtrise de géographie, Université Joseph Fourier, Grenoble, 118 p.

TALI.AKSEN L.M., 1995. - " A review of baseflow recession analysis ". Journal of Hydrology, 170, p 349-370.

VIRAMONTES D., 2000. - Comportement hydrodynamique des milieux dans le Haut bassin du rio Nazas (Sierra Madre Occidentale, Mexique); causes et conséquences de leur évolution. Thèse de Doctorat, Université Joseph Fourier, Grenoble, 430 p.

Viramontes D., Descroix L., 2003. - "Variability of overland flow in an endoreic basin of northern Mexico : the hydrological consequences of environment degradation ". Hydrological Processes, 17, p 1291-1306. 